\title{
PUBLIC EMPLOYEES' RISK AVERSION AND ORGANIZATIONAL CITIZENSHIP BEHAVIOR: THE EFFECTS OF ETHICAL LEADERSHIP, WORK CULTURE AND PUBLIC SERVICE MOTIVATION
}

\author{
Zainal Aqli \\ $\mathrm{PhD}$ in Public Administration \\ Universitas Tujuh Belas Agustus \\ Address: Jl. Semolowaru Praja No. 45, Surabaya, Indonesia. \\ E-mail: zainalaqli14269@gmail.com
}

\section{Ujianto}

Professor of Management, $\mathrm{PhD}$

Universitas Tujuh Belas Agustus

Address: Jl. Semolowaru Praja No. 45, Surabaya, Indonesia.

E-mail: ujiantojatim@gmail.com

\section{Ach Syafi'i}

$\mathrm{PhD}$ in Administration Science

Universitas Tujuh Belas Agustus

Address: Jl. Semolowaru Praja No. 45, Surabaya, Indonesia.

E-mail: akmadsyafii@untag-sby.ac.id

\begin{abstract}
The purpose of this study is to analyze the influence of ethical leadership, work culture, and public service motivation on risk aversion and its impact on organizational citizenship behavior. Risk aversion is the prudence of public employees so as not to violate laws and regulations. Risk aversion variable is treated as a consequent variable of ethical leadership, work culture, and motivation based on portfolio theory. The theory sees risk aversion as a contextual behavior, rather than as an individual characteristic. This study was designed with a quantitative descriptive design in a sample of 130 civil servants in the Tapin District Government, South Kalimantan Province, Indonesia. The analysis was carried out by structural equation modeling. The resulting model has a GFI 0.910; CFI 1,000; and RMSEA 0,000. The study found that ethical leadership has a positive effect on risk aversion but does not have a significant impact on organizational citizenship behavior; work culture has a positive effect on risk aversion and organizational citizenship behavior; public service motivation does not affect risk aversion but has a significant effect on organizational citizenship behavior;
\end{abstract}


and risk aversion has a positive effect on organizational citizenship behavior. This study has implications regarding the importance of the government to develop ethical leadership and a professional work culture in order to encourage the compliance of civil servants in the legislation. This research has a high originality value because it is the first in examining the determinants and antecedents of risk aversion in the context of public employees.

Keywords: ethical leadership; work culture; public service motivation; risk aversion; organizational citizenship behavior.

Citation: Aqli, Z., Ujianto \& Syafi'i, Ach (2019). Public Employees' Risk Aversion and Organizational Citizenship Behavior: The Effects of Ethical Leadership, Work Culture and Public Service Motivation. Public Administration Issue, no 6, (Special Issue II, electronic edition), pp. 7-22 (in English); DOI: 10.17323/1999-5431-2019-0-6-7-22.

\section{Background}

Employees in the public service environment have long been known to have a tendency for risk aversion (Dur \& Zoutenbier, 2013; Buurman, Delfgaauw, Dur \& van den Bossche, 2012). Risk aversion is a person's tendency to be very careful in taking risks (Leahy, 2001). Risk aversion is in fact one of the main reasons to pursue a career in public service: it provides a fixed income, a relatively stable career and a decent old age guarantee, in contrast to working in a private organization which is full of uncertainty. In other words, being a public servant is seen as a profession that is safe from risk. In the context of ongoing work, risk aversion can be seen as an attempt to be very careful not to violate the laws and regulations.

Civil servants in Indonesia are risk averse. Hongdiyanto (2014) found that a large proportion of Indonesians seek civil servant jobs because they want to have a stable income and pension package. Similarly, Loso (2008) used samples of 300 fresh bachelor graduates from three universities and found that the reasons to pursue a civil servant profession included salary (59.9\%), better future $(56.6 \%)$, pension package $(91.1 \%)$, senior benefits $(69.9 \%)$, and well-being $(67.8 \%)$. These all convey a risk averse attitude based on economic situation (Di Mauro and Musumeci, 2011). In addition, 67.2\% of the samples chosea civil servant profession because they perceived this profession to have a high status in society, indicating a social risk averse attitude.

Risk aversion could be a positive thing for the public service in terms of making sure the government is running well. Nevertheless, the Indonesian government has decreased the number of civil servants for efficiency reasons. In 2012, there were 4.6 million civil servants in Indonesia while in 2017, there were only 4.3 million - a decrease in the number of civil servants per 1,000 inhabitants from 19.7 to 18.5 ; lower than the Philippines and Vietnam (Tjiptoherijanto, 2018). The decreasing trend resulted in fiercer competition in gaining a public servant profession. Since part of the government efficiency is contributed to by individual civil servants' performance, there is a question about what role risk aversion plays in civil servant performance. Is risk aver- 
sion actually detrimental for today's more private-like government administration (Clark, 2016) in Indonesia?

While risk aversion may explain why someone chose a civil servant position, the same reason could also come into play in terms of maintaining the position of someone who is already in a civil servant position. This is intuitive, since bad behaviour would result in loss of salary, future prospects, etc., which were the main reasons for choosing the profession. Yet, Indonesian public service is known to have a high level of corruption. In 2018, it was proven that 2,357 civil servants were guilty of corruption, not to mention the unreported cases from around the archipelago (BBC, 7 September 2018). Corruption is extremely risky behaviour that should not be committed by an individual with high risk aversion. Meanwhile, corruption was cited as the negative predictor of public sector efficiency (Adam, Delis \& Kammas, 2011). Was the high level of corruption in public service linked to either low risk aversion or high risk aversion, as suggested by the Costa and Mainardes (2015) study? If it was, what organizational factors drive this risk taking behavior?

Unfortunately, risk aversion variables are very rarely used to predict organizational performance, including organizational citizenship behavior (Leahy, 2001). This variable is rarely used because risk aversion is assumed to be an individual characteristic variable rather than a conditional variable (Deckop et al, 2004). Portfolio theory from Leahy (2001) confirms that risk aversion is not an individual characteristic variable, but a conditional variable. Aversion of a risk is influenced by individual working conditions, in this case stressful working conditions, for example due to the existence of many regulations that regulate how a person must behave. Therefore, Leahy (2001) places risk aversion as a component of an employee's depressive decision dimension. Depressed employees will tend to take an aversive position on risk while non-depressed employees tend to be risk-neutral and even risk-taking. This was proven by Guiso, Sapienza, and Zingales (2018) who found that risk aversion varied with time and increases substantially after a crisis.

In line with this, it is important to consider what factors influence risk aversion in public employees. It can be said that there is no research that attempts to examine the factors that influence risk aversion in employees in the public sector. One study did examine the predictors of risk aversion in college students, and found that having a father who worked in the public sector increased the risk aversion of their children (De Paola, 2013). The reason for this lack of research has been explained above, namely due to errors in taking a theoretical perspective. If portfolio theory is used, there should be many studies that try to examine what variables influence risk aversion.

There are several variables that can possibly predict risk aversion, such as ethical leadership, work culture, and public service motivation. Each represent factors from a team, organizational, and individual level. Ethical leaders, as the name implies, would lead their followers to the ethical behaviour. Ethical norms, in addition to legal-institutional norms, is another restriction on public service employees, and potentially an even more risk averse attitude. This is supplemented by the preferred work culture chosen by the organization. 
From the individuals' side, public service motivation offers another restriction on the behaviour of public sector employees. Simultaneously, these three factors could limit risk taking behaviors, maintaining civic servants in their correct path of behaviors and increasing risk aversion.

The same three factors also can directly contribute to organizational citizenship behaviors. Organizational citizenship behavior is "individual behavior that is voluntary, not directly or explicitly recognized through a formal incentive system, and in aggregate encourages effective organizational functioning" (Podsakoff, MacKenzie, Paine \& Bachrach, 2000). Included in the category of organizational citizenship behavior is helping colleagues with their work, protecting the interests of the organization, giving advice, promoting the organization, and so on (Vigoda-Gadot \& Beeri, 2011). Organizational citizenship behavior is highly expected because it increases organizational efficiency and increases the likelihood of the organization achieving its goals (Popescu, Fistung \& Popescu, 2012). In addition, this activity can improve individual, group, and organizational performance (Rayner, Lawton \& Williams, 2012).

In itself, organizational citizenship behavior is ethical, hence it would be promoted by ethical leaders. Good work culture also should promote citizenship behavior because it increases organizational efficiency. Individual public service motivation, by definition, would focus on increasing public service quality, and one of the key predictors of public service quality is organizational citizenship behavior.

To test the proposed relationship above, this research was conducted on one of the local governments in Indonesia, namely the Regional Government of Tapin Regency, South Kalimantan Province. The research was carried out at the local government level because the local government was the worst public servant in Indonesia. The Indonesian Ombudsman found that $42.3 \%$ of 3,427 community reports in 2017 were directed at the poor service of local governments. This has continued to occur since 2015 (Rochmi, 2018). If the government tries to encourage extraordinary public services, it is very necessary for the government to maintain the compliance of public employees with the legislation, and this means that it is important for the government to increase employee risk aversion. Researchers put forward three variables that have the potential to increase employee risk aversion, namely ethical leadership, work culture, and public service motivation. Work culture and public service motivation are common variables in public management in Indonesia, while ethical leadership is a new variable that can provide a novelty for this research.

\section{Theoretical Review}

\section{Ethical Leadership}

The concept of leadership has been greatly developed with many conceptions. The commonly used leadership concept is transformational leadership. Even so, Li (2013) views transformational leadership as a starting point towards a leadership concept that is more oriented to ethical aspects. Ethical aspects 
are important in public service because public employees are responsible to all of the citizens and become a reflection of the quality of services provided by the ruling government.

In line with the aim of capturing the ethical aspects of leadership broadly, the concept of transformational leadership develops into authentic transformational leadership. The concept of authentic transformational leadership was further developed into authentic leadership by Avolio and Gardner in 2005 (Li, 2013). They get rid of the transformational concept of authentic leadership, making authentic leaders truly lead others according to morality and understand their subordinates honestly and accurately, regardless of whether the subordinate must be transformed or not.

The concept of ethical leadership then emerged through the thought of Brown et al (2005) based on social learning theory. Brown et al (2005) define ethical leadership as "the demonstration of normatively appropriate conduct through personal actions and interpersonal relationships, and the promotion of such conduct to followers through two-way communication, reinforcement, and decision-making". Riggio et al (2010) criticize Brown et al's (2005) definition as not capturing a complete ethical concept. A person who behaves maliciously and cruelly can be seen as an ethical leader by the definition insofar as these behaviors are considered normatively feasible in the organization he leads. Ethically, leaders should be based on a universal ethical concept. Riggio et al (2010) refer back to the notion of ethics as something that is the principle of right and wrong in life. Ethical leaders are none other than leaders who demonstrate and uphold these universal principles. Riggio et al (2010) further explore what principles are seen as universal ethical principles and find four principles of goodness, namely prudence, simplicity, fortitude, and justice. In line with this, Riggio et al (2010) define an ethical leader as "a leader whose personal characteristics and actions align with four cardinal virtues of prudence, temperance, fortitude, and justice".

Monahan (2012) takes a different approach. Monahan (2012) conducted surveys on leaders in organizations to find out practitioners' opinions on the meaning of ethical leadership. Monahan (2012) found that executives generally view that ethical leadership is nothing but "leaders having good character and the right values or being a person of strong character" (Monahan, 2012).

\section{Work Culture}

Most studies use organizational culture variables to predict organizational citizenship behavior. Even so, there is also the concept of work culture, at least at the practitioner level. A specific concept for Indonesia was issued through the State Apparatus Empowerment Ministerial Decree No. 25 / Kep / M.PAN / $4 / 2002$ concerning Guidelines for the Development of a Work Culture in the State Apparatus, which was updated through the Minister of State Apparatus Empowerment and Bureaucratic Reform Regulation No. 39 of 2012 concerning Guidelines for the Development of Work Culture. In this regulation, work culture is defined as "the attitudes and behaviors of individuals and groups based on values that are believed to be true and have become the nature and 
habits of carrying out daily tasks and work". In summary, work culture is defined as "a person's perspective in giving meaning to work". Work culture is also derived from the concept of organizational culture so that indicators of work culture will depend on their respective organizations. In fact, this regulation provides a number of steps that need to be taken to develop work culture indicators for each government institution.

\section{Public Service Motivation}

Regarding motivation, the literature has developed motivational concepts that are specific to public employees. This concept is called the Public Service Motivation (PSM). PSM is an intrinsic motivation variable that measures the extent to which a civil servant's motives are in carrying out public services. Motivation is individual, so it can capture predictors that determine the performance of civil servants from the personal aspect, as a complement to a universal work culture and collective ethical leadership.

There are three types of public service motivation, namely rational, normative and affective motivation. Rational reasons are motives for maximizing one's personal interests. This reason is operationalized in the form of interest in public decision making. The normative reason is the commitment to serve the public interest, achieve social justice, and carry out civil duties. Affective motivation is patriotism and self-sacrifice (Naff and Crum, 1999).

\section{Hypotheses}

Risk aversion in the scope of portfolio theory applies to all types of employees, regardless of whether they are a public or private worker. For public employees who have an initial mindset of risk aversion, risk aversion behavior can depart not from a depressive situation at work, but rather it has just become a generally accepted norm. Civil servants are faced with a large responsibility because the clients served have the potential to cover all citizens. In addition, public employees also have strict regulations in various aspects of service so that regulations become part of their daily work. With this, risk aversion is important to prevent violations of regulations.

In line with this, the positive influence of risk aversion can occur on performance, including organizational citizenship behavior. This positive relationship can occur because organizational citizenship behavior is an effort to encourage the achievement of public service goals. Therefore, it can be hypothesized that:

H1: Risk aversion positively affects organizational citizenship behavior

Ethical leadership has long been seen as a predictor of organizational citizenship behavior (Mayer et al, 2009; Shin, 2011; Kalshoven et al, 2011). Ethical leadership can have an effect on organizational citizenship behavior because employees learn socially from the example given by the leader and provide rewards to leaders and coworkers (Brown and Trevino, 2006; Toor and Ofori, 2009). As a result of strengthening the social goodness of leaders, organizational citizenship behavior emerges (Kacmar et al, 2011; Kacmar et al, 2013). In line 
with this, when dealing with a low public service situation, ethical leaders should try to encourage employees to comply with the laws and ethics of public services. These two things are restrictive and encourage public employees not to take risks by violating regulations. Therefore, ethical leadership should increase risk aversion. On this basis, the following hypotheses are put forward:

H2: Ethical Leadership has a positive effect on risk diversion

H3: Ethical leadership has a positive effect on organizational citizenship behavior

A good work culture should make employees more oriented towards serving the community. This is realized in the form of compliance with laws and regulations that have been designed in such a way as to improve public services. Employees can also be required to be more careful to avoid taking risks in serving the public interest. Even so, there has not been a more in-depth study of the impact of work culture on risk aversion. Researchers argue that employees will be more aversive to risk because they are faced with a low public perception of the performance of public employees. They will increasingly stick to the legislation to produce better public services than before. Therefore, the fourth and fifth hypotheses are:

H4: Work culture has a positive effect on employee risk aversion

H5: Work culture has a positive effect on organizational citizenship behavior

Anderfuhren-Biget et al (2010) found that public service motivation increases overall work motivation. Ritz et al (2016) conducted a meta-analysis of 239 previous studies on the motivation of public services. They found that public service motivation has an impact on job satisfaction, job choices in the public sector, individual performance, organizational commitment, early retirement intention, person organizational fit, organizational citizenship behavior, organizational performance, work motivation, work effort, use of performance data, stress related to employment, choice of intrinsic work, work commitment, mission valence, extrinsic incentive choices, choice to contribute, organizational attractiveness, quality of work, and responsiveness. The organizational citizenship behavior variable has a high level of agreement. Of the eight studies that examined the effect of public service motivation on organizational citizenship behavior, all found positive effects. Meanwhile, related to work stress, which is a predictor of risk aversion according to portfolio theory, there are four studies. Three of these studies showed negative effects while one did not show a significant relationship.

However, the relationship between PSM and risk aversion is unclear. If it is seen that risk aversion is the effect of depression, in accordance with portfolio theory, the motivation of public services should have a negative effect. Meanwhile, if risk aversion is seen as a form of compliance with laws and regulations, voluntary or forced, PSM should encourage employees to be more compliant with the regulations because they reflect good public services. We are more likely to see that there is a positive relationship between PSM and risk aversion, in accordance with the characteristics of employees in the public environment. In line with this opinion, it is hypothesized that:

H6: PSM will have a positive effect on risk aversion 
Previous research generally found that public service motivation has a positive and significant effect on organizational citizenship behavior (Ritz et al, 2016; Kim, 2009). Ritz et al (2016) found eight studies that examined the relationship between public service motivation on organizational citizenship behavior and all eight studies agreed that there was a positive relationship between public service motivation and organizational citizenship behavior. In line with this, it is hypothesized that:

H7: Public Service Motivation has a positive effect on Organizational Citizenship Behavior

\section{Research Methodology}

\section{Participants}

One hundred and ninety-two public employees (192) who worked in the Tapin District Government were contacted for their willingness to complete the research questionnaire. The final result is 130 respondents $(\mathrm{N}=130)$. Respondents consisted of $21 \%$ women and $79 \%$ men. The highest number of respondents have high school education (45\%). The remaining $11 \%$ have diploma education, $8 \%$ have junior high school education, and $36 \%$ have bachelor degrees. There are only six respondents with very low working experience (0-2 years). Meanwhile, the number of respondents with a high tenure of 10 years or more was 75 people. As for the rest, the number of respondents with 3-5 years of work was as many as 23 people and those with a working period of 6-9 years was as many as 26 people. In percentage terms, the most worked period is 10 years or more, namely $57.7 \%$, followed by a $6-9$ year work period of $20.0 \%$ and a $3-5$ year work period of $17.7 \%$. Employees with a working period of $0-2$ years are the least with a percentage of only $4.6 \%$.

\section{Research Instrument}

Measurement of risk aversion uses the Risk Aversion scale from Leahy (2001) modified into three items: threat, uncertainty, and risk taking. Organizational citizenship behavior was developed using instruments from Niehoff and Moorman (1993) with five indicators: altruism, conscientiousness, sportsmanship, courtesy, and civic virtue.

The ethical leadership instrument, developed from Brown et al (2005), consists of four items: critical attitude, rational attitude, autonomous attitude, and fair attitude. Meanwhile, the work culture variable is measured using five indicators: basic assumptions about work, attitudes toward work, behavior when working, work environment, and work ethic. To measure the PSM, we use the public service motivation instrument from Perry (1996) with three indicators: rational, normative and affective motives. All instruments are measured in the five Likert Scale.

\section{Analysis}

We use CFA (Confirmatory Factor Analysis) to determine the validity of the scales. CFA allows for calculating the feasibility of indicators in latent 
variables to be a real indicator which actually contains one latent variable to be measured. All variables are examined for validity using CFA with minimum acceptance requirements based on the CFI model match indicator. CFI was chosen because it prevents incorrect calculations due to small samples. CFI has a threshold of $>0.9$.

Before testing the hypothesis, a model suitability test is carried out using a structural equation model with a maximum likelihood estimate (ML - Maximum Likelihood). Model compatibility was tested using Goodness of Fit index (GFI), Comparative Fit Index (CFI), and Root Mean Square Error of Approximation (RMSEA) (Rigdon, 1996).

\section{Results}

\section{Description of the Sample}

Based on the results of the questionnaire, it was found that the description of respondents' ratings on the ethical leadership variables showed high ethical leadership. This was indicated by an average score of 4.08. Indicators of ethical leadership that were rated highest by respondents were regarding critical attitudes, with an average value of 4.20 , while the lowest indicator of ethical leadership was rational attitude, namely with an average value of 4.00 .

Respondents' assessment of the work culture variable has a mean score of 3.98. The indicator of work culture that was rated highest by respondents was the basic assumptions about work, namely with an average value of 4.11 , while the indicator of work culture that was rated lowest by respondents was the behavior when working, with a mean score of 3.80 .

PSM is perceived as high, indicated by an average score of 3.68. Public service motivation indicators that were rated highest by respondents were regarding affective motives, with an average score of 3.83 , while public service motivation indicators that were rated lowest by respondents were normative motives, with a mean score of 3.47 .

Concerning Risk Aversion, employees at Tapin Regency gave a mean score of 3.75. The highest risk aversion indicator was the attitude to face threats, with an average value of 3.86, while the lowest risk aversion indicator was the courage to take risks, with an average score of 3.59.

Respondents' assessment of organizational citizenship behavior variable shows a high value, indicated by the average score of 3.95. The highest indicator of organizational citizenship behavior by respondents was on conscientiousness and civic virtue, each with an average score of 4.08 , while the lowest indicator of organizational citizenship behavior by respondents was altruism, namely with an average value of 3.70 .

\section{Measurement Model}

CFA tests results on exogenous constructs consisting of ethics leadership, work culture, and public service motivation as well as endogenous variables consisting of risk aversion and organizational citizenship behavior, indicating that all indicators have loading factor values greater than 0.50 , so that the in- 
dicators are valid in reflecting the latent constructs and can be used for further analysis. The GFI value was more than 0.90 indicating an exogenous and endogenous construct formed by indicators that fit with the data.

\section{Hypothesis Testing}

The results of hypothesis testing are displayed in Table 1 and Figure 1. The first hypothesis of the current study is on the relationship between risk aversion and OCB. It was hypothesized that a positive relationship would exist between risk aversion and OCB. The hypothesis was strongly supported. Risk aversion was positively related to OCB.

Table 1

\section{Study Variables Estimates by Model Paths $(\mathrm{GFI}=.910, \mathrm{CFI}=1.000 \mathrm{RMSEA}=.000)$}

\begin{tabular}{|l|c|c|c|c|}
\hline \multicolumn{1}{|c|}{ Model Paths } & & & $\boldsymbol{\beta}$ & $\mathbf{p}$ \\
\hline RA & $\leftarrow$ & EL & .346 & $* * *$ \\
\hline OCB & $\leftarrow$ & EL & .085 & .383 \\
\hline RA & $\leftarrow$ & WC & .375 & $* * *$ \\
\hline OCB & $\leftarrow$ & WC & .260 & $*$ \\
\hline RA & $\leftarrow$ & PSM & .056 & .540 \\
\hline OCB & $\leftarrow$ & PSM & .269 & $*$ \\
\hline OCB & $\leftarrow$ & RA & .250 & $*$ \\
\hline
\end{tabular}

Notes: GFI = Goodness of Fit Index; CFI = Comparative Fit Index; RMSEA = Root mean square error of approximation; RA = Risk Aversion; OCB = Organizational Citizenship Behavior; EL = Ethical Leadership; WC $=$ Work Culture; PSM = Public Service Motivation.

${ }^{* * *} \mathrm{p}$ is significant at .000 level;

${ }^{* *} \mathrm{p}$ is significant at .01 level;

${ }^{*} \mathrm{p}$ is significant at .05 level.

The second hypothesis advanced in this study centered on the relationship between ethical leadership and risk aversion. It was proposed that with the ethical leadership, employee risk aversion will increase. This hypothesis was supported by the findings of the current study. The relationship was indeed positive. The third hypothesis is on the relationship between ethical leadership and OCB. This hypothesis however is not supported by the findings.

The next set of hypotheses expected that Work Culture will influence Risk Aversion and OCB positively. We find support for both hypotheses. However, for the last set of hypotheses, which expected that PSM will influence Risk Aversion and OCB positively, we only found support for PSM and OCB relationship. No significant relationship was found between PSM and Risk Aversion. 


\section{Figure 1: Statistical Model $(\mathrm{GFI}=.910, \mathrm{CFI}=1.000 \mathrm{RMSEA}=.000)$}

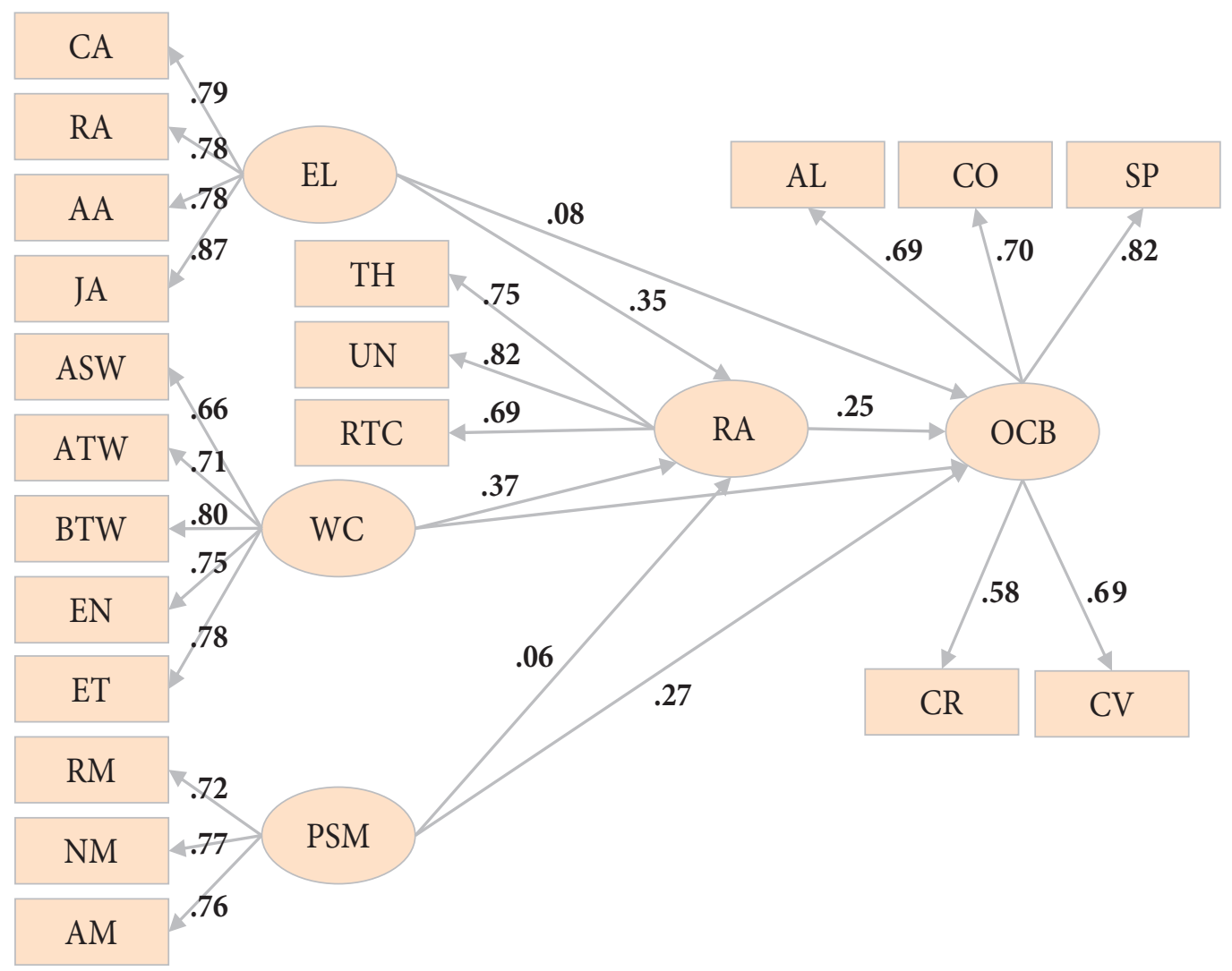

Notes: $\mathrm{RA}=$ Risk Aversion; $\mathrm{OCB}=$ Organizational Citizenship Behavior; EL = Ethical Leadership; $\mathrm{WC}=$ Work Culture; PSM = Public Service Motivation; CA = Critical Attitude; RA = Rational Attitude; $\mathrm{AA}=$ Autonom Attitude; JA = Justice Attitude; ASW = Assumption about Working; ATW = Attitude on Working; BTW = Behavior on Working; EN = Work Environment; ET = Work Ethos; RM = Rational Motive; $\mathrm{NM}=$ Normative Motive; $\mathrm{AM}=$ Affective Motive; $\mathrm{TH}=$ Threat; UN = Uncertainty; RTC = Risk Taking Courage; $\mathrm{AL}=$ Altruism $; \mathrm{CO}=$ Conscientiousness; $\mathrm{SP}=$ Sportsmanship $\mathrm{CR}=$ Courtesy; $\mathrm{CV}=$ Civic Virtue .

\section{Discussion}

In line with the hypothesis, risk aversion has a positive effect on OCB. Risk aversion research on organizational citizenship behavior has never been done. The only research that comes close to resembling this study was the study of Deckop et al (2004) who found that risk aversion moderated the relationship between incentives and organizational citizenship behavior negatively. That is, the higher the risk aversion, the lower the influence of incentives on organizational citizenship behavior. This means that employees with high risk aversion will still be trying less to achieve organizational citizenship behavior even though they have been given incentives for that behavior. Conversely, employees with low risk aversion will enjoy expressing organizational citizenship behavior, especially if this behavior receives incentives or recognition from the organization. This causes the lower risk aversion and higher effect of incentives on citi- 
zenship behavior. The finding that risk aversion has a positive effect on OCB in the present study is contrary to this finding but it is understandable given that risk aversion is very important in the context of public services. Under this condition, risk aversion will encourage other employees to remain in the corridor of the legislation. The resulting collectivity is important in order to support good public services in accordance with regulations.

The finding that ethical leadership has a positive impact on risk aversion shows that ethical behavior by superiors provides support for employees to take action on ethical risk aversion. Employees become aware of what should be done and what should not be done so that they do not dare to take risks in doing something that is not feasible legally or ethically, which can cause problems in providing public services.

Even so, the results of the present study are not in line with previous studies which found positive effects of ethical leadership on organizational citizenship behavior (Mayer et al, 2009; Shin, 2011; Kalshoven et al, 2011). The current study found that ethical leadership has no effect on organizational citizenship behavior. This can be caused by ethical leaders more oriented on task performance and not paying attention to ethical issues in contextual performance such as organizational citizenship behavior.

Meanwhile, work culture has a positive effect on risk aversion. The higher the work culture, the higher the risk aversion of employees. In line with this, work culture also has a positive effect on OCB. The positive influence of work culture on OCB shows that work culture is oriented towards achieving goals, and this can be done through OCB. A good work culture will produce professional trust that can help in resource exchange, social exchange, communication, cooperation between employees, innovation, and organizational functioning (Jones and George, 1998; Putnam, 1993).

PSM is not found to affect risk aversion. This result is counterintuitive because motivation should support employees in being obedient of the rules. This situation can be explained if the PSM is double edged for risk aversion. On the one hand, motivation encourages employees to work as best they can in accordance with the regulations that apply to their profession. On the other hand, motivation also encourages employees to take risky initiatives if the existing regulations have not been sufficient for them to provide meaningful public services.

The positive relationship between PSM and OCB can be explained by the existence of the civic virtue concept, which is an indicator of OCB. This concept developed in an academic setting at the April 1984 meeting of the National Council of the American Public Administration Society (Upton, 1989). This council stated that civic virtue is a heroic love for the public interest, serving justice, willingness to sacrifice wealth and comfort for the welfare of society, and unite the soul in providing public services. A person who has high PSM will try to provide public goods (Upton, 1989). For them, job satisfaction comes from helping others, and almost the only thing that is important in their work is doing something that is beneficial to the community or organization (Upton, 1989). Therefore, the public goods, also called public service ethics, has a strong relationship with the PSM. 


\section{Conclusion}

This study contributes to the ethical leadership and work culture literature by highlighting the role of risk aversion. When leaders act according to generally accepted norms, employees will perceive additional rules that should not be violated, which in turn makes them more aversive to risk. Meanwhile, a professional work culture helps in increasing risk aversion because it affirms professionalism characterized by adherence to regulations that guide the profession.

This study has implications for the importance of public service organizations to take steps that make public employees more compliant with the legislation through increased risk aversion. The government can train leaders to become ethical leaders who are able to keep employees compliant with legal and ethical rules. In addition, a positive work culture must be further instilled so that employees can better understand that compliance with regulations is very important in order to provide good public services.

Although it has theoretical and practical implications as above, this research still has its limitation. Because this study uses cross-sectional design, it is not possible for researchers to make a complete causal conclusion about the influence of ethical leadership, work culture, and public service motivation on the risk aversion and organizational citizenship behavior. It is possible that organizational citizenship behavior actually becomes the motive for employees to comply with the organization, thereby increasing risk aversion because it is indebted to the organization, in accordance with social exchange theory. That is, there is a possibility that OCB influences risk aversion, rather than risk aversion affecting organizational citizenship behavior. Nicholson-Crotty, Nicholson-Crotty, and Fernandez (2016) even show that organizational performance have some influence on risk averse behavior. As a result, the hypothetical model proposed by this study can be better examined using repeated measurements or through longitudinal designs, where data is collected several times over a fairly long time interval.

Another limitation is the relatively small amount of respondents. There are only 130 respondents used in this research. The sample size could explain some insignificant relationships in this research. Hence, future research should be done to replicate with a larger sample size, especially in the field of the impact of PSM on the risk aversion. 


\section{REFERENCES}

1. Adam, A., Delis, M. \& Kammas, P. (2011). Public Sector Efficiency: Leveling the Playing Field between OECD Countries. Public Choice, vol. 146, no 1-2, pp. 163-183.

2. Anderfuhren-Biget, S., Varone, F., Giauque, D. \& Ritz, A. (2010). Motivating Employees of the Public Sector: Does Public Service Motivation Matter? International Public Management Journal, vol. 13, no 3, pp. 213-246.

3. $\quad B B C$ (7 September 2018). Ribuan PNS Tersangkut Korupsi Masih Terima Gaji, Negara Rugi Puluhan Miliar Tiap Bulan (Thousands of Corrupt Civil Servants Still Have Salary, the State Loss Tens of Billions Every Month). Available at: https://www.bbc.com/indonesia/indonesia-45432000 (accessed: 20 February, 2019).

4. Brown, M.E. \& Treviño, L.K. (2006). Ethical Leadership: A Review and Future Directions. The Leadership Quarterly, vol. 17, no 6, pp. 595-616.

5. Brown, M. E., Treviño, L.K. \& Harrison, D. A. (2005). Ethical Leadership: A Social Learning Perspective for Construct Development and Testing. Organizational Behavior and Human Decision Processes, vol. 97, no 2, pp. 117-134.

6. Buurman, M., Delfgaauw, J., Dur, R. \& Van den Bossche, S. (2012). Public Sector Employees: Risk Averse and Altruistic? Journal of Economic Behavior \& Organization, vol. 83, no 3, pp. 279-291.

7. Clark, A. F. (2016). Toward an Entrepreneurial Public Sector: Using Social Exchange Theory To Predict Public Employee Risk Perceptions. Public Personnel Management, vol. 45, no 4, pp. 335-359.

8. Costa, L.D. A. \& Mainardes, E.W. (2016). The Role of Corruption and Risk Aversion in Entrepreneurial Intentions. Applied Economics Letters, vol. 23, no 4, pp. 290-293.

9. De Paola, M. (2013). The Determinants of Risk Aversion: the Role of Intergenerational Transmission. German Economic Review, vol. 14, no 2, pp. 214-234.

10. Deckop, J.R., Merriman, K.K. \& Blau, G. (2004). Impact of Variable Risk Preferences on the Effectiveness of Control by Pay. Journal of Occupational and Organizational Psychology, vol. 77, no 1, pp. 63-80.

11. Di Mauro, C. \& Musumeci, R. (2011). Linking Risk Aversion and Type of Employment. The Journal of Socio-Economics, vol. 40, pp. 490-495.

12. Dur, R. \& Zoutenbier, R. (2015). Intrinsic Motivations of Public Sector Employees: Evidence for Germany. German Economic Review, vol. 16, no 3, pp. 343-366.

13. Guiso, L., Sapienza, P. \& Zingales, L. (2018). Time Varying Risk Aversion. Journal of Financial Economics, vol. 128, no 3, pp. 403-421.

14. Hongdiyanto, C. (2014). Identifikasi Kepemilikan Entrepreneurial Spirit Mahasiswa Universitas Ciputra dari Kawasan Timur Indonesia (Identification of Entrepreneurial Spirit of Ciputra University Students from Eastern Part of Indonesia). Jurnal Entrepreneur dan Entrepreneurship, vol. 3, no 2, pp. 199-210. 
15. Jones, G.R. \& George, J.M. (1998). The Experience and Evolution of Trust: Implications for Cooperation and Teamwork. Academy of Management Review, vol. 23, no 3, pp. 531-546.

16. Kacmar, K.M., Andrews, M.C., Harris, K.J. \& Tepper, B.J. (2013). Ethical Leadership and Subordinate Outcomes: The Mediating Role of Organizational Politics and the Moderating Role of Political Skill. Journal of Business Ethics, vol. 115, no 1, pp. 33-44.

17. Kacmar, K.M., Bachrach, D. G., Harris, K.J. \& Zivnuska, S. (2011). Fostering Good Citizenship Through Ethical Leadership: Exploring the Moderating Role of Gender and Organizational Politics. Journal of Applied Psychology, vol. 96, no 3, pp. 633.

18. Kalshoven, K., Den Hartog, D. N. \& De Hoogh, A.H. (2011). Ethical Leadership at Work Questionnaire (ELW): Development and Validation of a Multidimensional Measure. The Leadership Quarterly, vol. 22, no 1, pp. 51-69.

19. Kim, S. (2009). Revising Perry's Measurement Scale of Public Service Motivation. The American Review of Public Administration, vol. 39, no 2, pp. 149-163.

20. Leahy, R.L. (2001). Depressive Decision Making: Validation of the Portfolio Theory Model. Journal of Cognitive Psychotherapy, vol. 15, no 4, pp. 341-362.

21. Li, C. (2013). Ethical Leadership in Firms: Antecedents and Consequences. The University of Alabama.

22. Loso, L. (2008). Kecenderungan Sarjana Menjadi Pegawai Negeri Sipil (PNS) yang Berdampak Rendahnya Minat Berwirausaha di Eks Karesidenan Pekalongan (Bachelor Propensity to Work as Civil Servants and its Effects to Low Level of Entrepreneurship Intention in Pekalongan Ex-Residency). Pena Justisia Jurnal Media Komunikasi Dan Kajian Hukum, vol. 7, no 13, pp. 1-20.

23. Mayer, D.M., Kuenzi, M., Greenbaum, R., Bardes, M. \& Salvador, R.B. (2009). How Low Does Ethical Leadership Flow? Test of a Trickle-Down Model. Organizational Behavior and Human Decision Processes, vol. 108, no 1, pp. 1-13.

24. Monahan, K. (2012). A Review of the Literature Concerning Ethical Leadership in Organizations. Emerging Leadership Journeys, vol. 5, no 1, pp. 56-66.

25. Naff, K.C. \& Crum, J. (1999). Working for America: Does Public Service Motivation Make a Difference? Review of Public Personnel Administration, vol. 19, no 4, pp. 5-16.

26. Nicholson-Crotty, S., Nicholson-Crotty, J. \& Fernandez, S. (2017). Performance and Management in the Public Sector: Testing a Model of Relative Risk Aversion. Public Administration Review, vol. 77, no 4, pp. 603-614.

27. Niehoff, B.P. \& Moorman, R.H. (1993). Justice as a Mediator of the Relationship between Methods of Monitoring and Organizational Citizenship Behavior. Academy of Management Journal, vol. 36, no 3, pp. 527-556.

28. Perry, J.L. (1996). Measuring Public Service Motivation: An Assessment of Construct Reliability and Validity. Journal of Public Administration Research and Theory, vol. 6, no 1, pp. 5-22.

29. Podsakoff, P.M., MacKenzie, S.B., Paine, J.B. \& Bachrach, D.G. (2000). Organizational Citizenship Behaviors: A Critical Review of the Theoretical and Empirical Literature and Suggestions for Future Research. Journal of Management, vol. 26, no 3, pp. 513-563. 
30. Popescu, A.M., Fistung, D.F. \& Popescu, T. (2012). Organizational Citizenship Behavior Activity Leverage Optimization in Virtual Enterprise. Procedia Economics and Finance, vol. 3, pp. 381-386.

31. Putnam, R.D. (1993). The Prosperous Community. The American Prospect, vol. 4, no 13, pp. 35-42.

32. Rigdon, E.E. (1996). CFI versus RMSEA: A Comparison of Two Fit Indexes for Structural Equation Modeling. Structural Equation Modeling: A Multidisciplinary Journal, vol. 3, no 4, pp. 369-379.

33. Riggio, R.E., Zhu, W., Reina, C. \& Maroosis, J.A. (2010). Virtue-based Measurement of Ethical Leadership: The Leadership Virtues Questionnaire. Consulting Psychology Journal: Practice and Research, vol. 62, no 4, pp. 235.

34. Ritz, A., Brewer, G. A. \& Neumann, O. (2016). Public Service Motivation: A Systematic Literature Review and Outlook. Public Administration Review, vol. 76, no 3, pp. 414-426.

35. Rochmi, M. (2018). Pemerintah Daerah Menjadi Pelayan Publik terburuk [Local Government is the Worst Public Service Providers]. Available at: https://beritagar.id/artikel/berita/ pemerintah-daerah-menjadi-pelayan-publik-terburuk (accessed: 4 July, 2018).

36. Shin, Y. (2012). CEO Ethical Leadership, Ethical Climate, Climate Strength, and Collective Organizational Citizenship Behavior. Journal of Business Ethics, vol. 108, no 3, pp. 299-312.

37. Tjiptoherijanto, P. (2018). Reform of the Indonesian Civil Service: Looking for Quality. Economics World, vol. 6, no 6, 433-443.

38. Toor, G. \& Ofori, G. (2009). Ethical Leadership: Examining the Relationships with Full Range Leadership Model, Employee Outcomes, and Organizational Culture. Journal of Business Ethics, vol. 90, no 4, pp. 533.

39. Upton, G.L.H. (1989). The Concept of Public Service Ethic as a Differentiating Factor Between Public and Private Professionals: Construct Development and Application. PhD Dissertation. Texas Tech University.

40. Vigoda-Gadot, E. \& Beeri, I. (2011). Change-oriented Organizational Citizenship Behavior in Public Administration: The Power of Leadership and the Cost of Organizational Politics. Journal of Public Administration Research and Theory, vol. 22, no 3, pp. 573-596.

41. Rayner, J., Lawton, A. \& Williams, H.M. (2012). Organizational Citizenship Behavior and the Public Service Ethos: Whither the Organization? Journal of Business Ethics, vol. 106, no 2, pp. 117-130. 